\title{
Bioremediation of Textile and Tannery Effluents - An Overview
}

\author{
A. Barathi ${ }^{1}$, J. Hemapriya ${ }^{1}$, Ramya Gunasekaran ${ }^{2}$, Kayeen Vadakkan ${ }^{3}$, \\ A. Shyamala ${ }^{4}$, Aswini Ravi ${ }^{5}$ and S. Vijayanand ${ }^{2 *}$
}

\author{
${ }^{1}$ Department of Microbiology, DKM College, Vellore, Tamilnadu, India \\ ${ }^{2}$ Department of Biotechnology, Thiruvalluvar University, Vellore, Tamilnadu, India \\ ${ }^{3}$ Department of Biotechnology, Sri Sankara College, Kanchipuram, Tamilnadu, India \\ ${ }^{4}$ Department of Biotechnology, St. Mary's College, Thrissur, Kerala, India \\ ${ }^{5}$ Department of Biotechnology, DKM College, Chennai, Tamilnadu, India
}

*Corresponding author

\section{A B S T R A C T}

\section{Keywords}

Azo dyes,

Biodegradation,

Chromium,

Effluent, Tannery,

Textile

Article Info

Accepted:

25 October 2020

Available Online:

10 November 2020
Water is considered to be one of the essential resources for the survival of living beings. The vital resource is exposed to toxic pollutant due to the untreated industrial discharge from tannery, textile and other industries. Effluents discharged from the tannery and textile industries contains an ample of heavy metals and other toxic azo dyes which affects the living beings including aquatic and terrestrial flora and fauna. The removal of this toxic compounds from the water bodies has become a challenge to the human society. Various treatments are used for the removal of these toxic compounds but due to its undesirable features such as partial removal, higher maintenance cost these methods are considered as ineffective process. Microbes remain as a promising candidate in bioremediation which effectively degrade the xenobiotic component such as hexavalent chromium and toxic azo dyes completely from the environmental bodies. This review concentrates on the tannery and textile effluents and the general treatment methods used for the remediation of the effluents from these sectors.

\section{Introduction}

Environmental pollution is the major problem caused by the anthropogenic activities where, human pollute the biological system in several ways. Evolution of various types of industries contributes significant growth economically to the country on the other hand, these industries release ample of waste into the environment in the form of liquid and solid matter. Among various industries, tanneries and textile industries play a vital role in the discharging large amount of waste in the form of effluent. The waste material of these industries includes organic and inorganic constituents, which are highly toxic, carcinogenic and mutagenic in nature. This industrial discharge disturbs the aquatic system which deteriorations the eminence of the aquatic bodies. These wastes contain more amounts of heavy metals and complex azo dyes thus greatly affect the physic-chemical 
properties of soil and water. Due to adverse environmental impacts the effluents released from tanneries and textile industries are given much importance during treatment process. Removal of waste from effluents is considered to be an essential process before letting out the effluent. Common issues arouse due to the improper sewage treatment and its disposal into the environment includes soil and water pollution, diseases, obnoxious odour, fire hazards etc., (Sarker et al., 2013). Various physical and chemical methods were introduced for the removal of the xenobiotic components from the industrial effluents. Adsorption, membrane filtration, ion exchange, and chemical reduction are some of the methods used for the cleaning up the industrial discharge. Due to high-cost instrumental set up, less efficiency and complicated operational procedures these techniques were found to be inefficient methods. The environment gets highly polluted through increased population, industrialization and various undesirable activities. Though, many techniques are available for the removal and/or recovery of xenobiotics from the tannery and textile effluents, none of the method showed complete removal of these foreign substance from the effluents. This complexity urges the industries to design and construct an effective treatment method for the removal of the xenobiotics. To overcome these complications, a novel technique was introduced, which encompasses microorganism either the contribution of individual organism or as a consortium. Since this method involves living organism it is referred as Biological treatment method. This microbial treatment was found to be efficient with low-cost substrate and easy and faster degradation of heavy metals and other carcinogenic dyes present in the effluent. Microbes like Algae, fungi, and bacteria were highly studied in the removal of toxic materials from the runoff.

\section{Tannery and its major pollutants}

\section{Tanning}

Tanning is one of the ancient processes involved in the leather tanning industries. In this process, the animal products are protected from decomposing and transferred into usable products. India holds third place in leather production and export. Leather industries are considered to be one of the greatest contributors to economy of leather. More than 3000 tanneries are installed in the various parts of the countries which broadly includes Tamilnadu, West Bengal, Uttar Pradesh, Andhra Pradesh, Karnataka, Maharashtra, Rajasthan and Punjab (Chaudhary et al., 2017). Vast disposal of the effluents from the tannery industries converted the agricultural land to infertile field (Mohan and Devi, 2015). The waste disposed from the tannery depends upon the leather process taking place in the tannery. These effluents normally contain abundant amount of chromium, sulfates, acids, dyes, ammonium, oils and other organic substances (Hasegawa et al., 2011).

\section{Chromium}

Chromium $(\mathrm{Cr})$ is a lustrous and hard chemical element. Due to its hardness and stability chromium takes an important role in many processing industries despite its toxicity (Panda and Sarkar, 2012). Cr salt is highly used in the tannery industries in processing the animal products after reaction, the $\mathrm{Cr}$ salt is converted into two different forms namely trivalent (III) and hexavalent chromium (VI). The toxicity of the former is very lesser when compared with the later form. Hexavalent chromium (Cr (VI)) is reported to be one of the toxic metals which has the ability to dissolve in the water and penetrate into the living cells and get interconnected with the essential cellular molecules such as proteins 
and nucleic acids (Samrithi and Usha, 2012). It is also stated that, when these toxic meals get in contact with human beings it results in various toxic effects in human system. Respiratory disorders such as itching, irritation, swelling, allergies are some of the respiratory disorders that occurs due to the $\mathrm{Cr}(\mathrm{VI})$ exposure. Lung cancer, renal disorder, epidermal disorders are some of the adverse effects of $\mathrm{Cr}(\mathrm{VI})$ exposure. Apart from these cellular toxicities, the impact of $\mathrm{Cr}$ on DNA was reported where the toxicity affects the gene and cause mutation (Farag and Zaki, 2010; Samrithi and Usha, 2012).

\section{Sulfides}

Sulfides are inorganic anions of sulfides; these inorganic substances are abundantly found in the tannery effluents. Exposure to these compounds in low concentration causes dizziness, tired, headache and it also leads to disorder in the central nervous system. Whereas, exposure to sulfides in higher concentration leads to the death. The higher concentration of Sulfide for human consumption is $250 \mathrm{mg} / \mathrm{L}$ and lower concentration was determined as 0.025 and $0.25 \mu \mathrm{g} / \mathrm{L}$ in clean potable water (Midha and Dey, 2008; Balasubramanian and Pugalenthi, 2000).

\section{Other tannery pollutants}

Apart from these major tannery pollutants, there are many pollutants which are reported to be a part in the tannery effluent. Azo dyes, cadmium, cobalt, copper, selenium, mercury, arsenic, lead are few heavy metals present in the tannery effluents. These metals are reported to cause severe and adverse effects to human beings when exposed to larger time. Few are generally considered as beneficially metal which enhances the growth of terrestrial and aquatic plants. On the other hand, presence of these beneficially metals like copper in higher concentration turn as toxic metals which inhibits the regular growth of plant. But other metals such as lead, arsenic, cadmium are considered to be toxic element for both plants and animals. Cadmium which is not an essential element when present in the soil with varying $\mathrm{pH}$ acts as a toxic metal and hinders the growth of animals and plants. These metals are also responsible for bone disorder when it gets in contact with the human and animals in water as contaminant.

\section{Textile effluents and its contaminants}

Colorants are elements that are capable of transmitting its nature to the compounding substance. Generally, these colorants are highly used in industries such as textile, tannery, paint, cosmetics, food, pharmaceutic industries. These compounds are normally used alone as a coloring agent or combined with the intensifiers which enhances the color of the dye. Colorants are generally used for enhancing the visual characterization of the compound which in turn plays an essential role in determining the value of the compound in the global market. In general, colorants are classified into two major categories i.e., Natural colorant and synthetic colorant. Natural colorants are pigments extracted from natural sources such as plants and animals. Synthetic colorants are coloring substances manufactured chemically in the laboratories or in industries with low-cost products. Azo dyes are the major cheap colorant used for coloring the materials. These dyes are generally considered as synthetic dyes that act as a substitute for natural dyes due to its cost, synthesis and processing time. Apart from vast advantages like stability, intensity, durability these azo dyes possess negative role in the environmental aspect. Due to the presence of strong azo bond in it these dyes are extremely hard for dissociating in the environmental conditions. Thus, these compounds when discharged in the effluent 
remains in the soil and the aquatic bodies as such and create adverse effects to the aquatic and terrestrial living organisms. Accumulation of azo dye in the environmental bodies makes them unfit for the regular activities such as irrigation, consumption and domestic usage.

\section{Dyeing}

Dyes in textile and other coloring industries use synthetic colorants due to its easy and low-cost availability. These are generally derived from coal tar and petroleum-based intermediates. These dyes basically called as chromophores and they contain electrons responsible for intensifying the color called auxochromes. Chromophores are generally, azo (-NON-), carbonyl (-COO), methine, carboxy (-COO)group. The chemical structure and common name of the azo dyes are listed in the table 1. These azo dyes are classified into various types based on the azo linkage present in the chemical structure namely monoazo $(\mathrm{Z}-\mathrm{N}=\mathrm{N}-\mathrm{W})$, diazo $(-\mathrm{N}=\mathrm{N}-)$, trisazo, polyazo, and azoic. These dyes are the major synthetic chromatic substance which are used in several dyeing industries.

Table.1 Structure and common name of few azo dyes

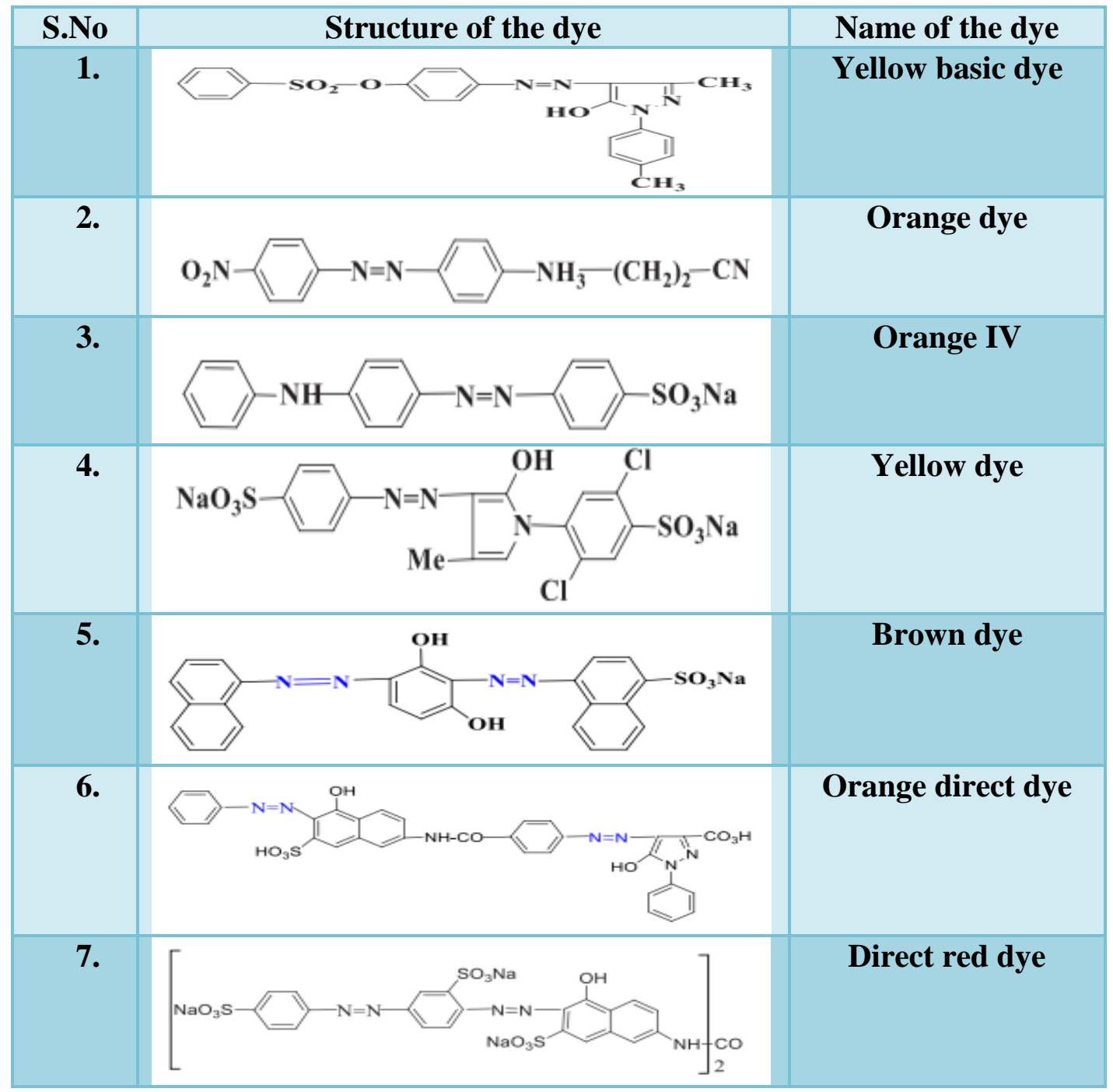


Table.2 Decolorization of Synthetic Dyes by Bacterial Consortium

\begin{tabular}{|c|c|c|c|c|}
\hline SI. No & Consortium & Microbial Composition & Dye & Reference \\
\hline 1 & HM-4 & $\begin{array}{l}\text { Bacillus cereus } \mathrm{BN}-7 \\
\text { Pseudomonas putida } \mathrm{BN}-4 \\
\text { Pseudomonas fluorescens } \mathrm{BN}-5 \\
\text { Stenotrophomonas } \\
\text { acidaminiphilia } \mathrm{BN}-3\end{array}$ & $\begin{array}{l}\text { Acid Red-88 } \\
\text { Acid Red-119 } \\
\text { Reactive Red-120 } \\
\text { Acid Blue-113 } \\
\text { Acid Brown-100 }\end{array}$ & $\begin{array}{l}\text { Khehra et al., } \\
\text { (2005) }\end{array}$ \\
\hline 2 & JW-2 & $\begin{array}{l}\text { Paenibacillus polymyxa } \\
\text { Micrococcus luteus } \\
\text { Micrococcus } \text { sp. }\end{array}$ & Reactive Violet 5R & $\begin{array}{l}\text { Moosvi et al., } \\
\text { (2007) }\end{array}$ \\
\hline 6 & GR & $\begin{array}{l}\text { Proteus vulgaris } \\
\text { Micrococcus glutamicus }\end{array}$ & Scarlet R & $\begin{array}{l}\text { Saratale } \text { et al., } \\
(2009)\end{array}$ \\
\hline 7 & SDM & $\begin{array}{l}\text { Providencia sp. SDS } \\
\text { Pseudomonas aeruginosa } \mathrm{BCH}\end{array}$ & Red HE3B & $\begin{array}{l}\text { Phugare et al., } \\
\text { (2011) }\end{array}$ \\
\hline 8 & PVN-5 & Unknown & $\begin{array}{l}\text { Direct Red } 28 \\
\text { Direct Blue } 8\end{array}$ & $\begin{array}{l}\text { Hemapriya and } \\
\text { Vijayanand. (2013) }\end{array}$ \\
\hline 8 & TVU-AO64 & Halophilic bacterial consortium & Acid orange & $\begin{array}{l}\text { Vijayanand et al., } \\
\text { (2017) }\end{array}$ \\
\hline
\end{tabular}

Table.3 Dye Decolorization by Pure Cultures of Gram +ve Bacterial Isolates

\begin{tabular}{|c|c|c|}
\hline Bacteria & Dye & Reference \\
\hline Bacillus gordonae & Tectilon Blue 4R-01 & Walker and Weatherley (2000) \\
\hline Clostridium perfringens & Bromophenol Blue & Kim et al., (2002) \\
\hline Kerstersia sp. strain VKY 1 & Sulphonated dye & Vijaykumar et al., (2007) \\
\hline Bacillus firmus & Mono azo dye & Arora et al., (2007) \\
\hline Bacillus cereus strain DCII & Anthraquinone dye & Deng et al., (2008) \\
\hline Bacillus subtilis HM & Fast Red & Mabrouk and Yusef (2008) \\
\hline Bacillus thuringiensis & Acid Red-119 & Dave and Dave (2009) \\
\hline Bacillus sp. TVU-M4 & Methyl Orange & Shyamala et al., (2014) \\
\hline
\end{tabular}

Table.4 Dye Decolorization by Pure Cultures of Gram -ve Bacterial Isolates

\begin{tabular}{|l|l|l|}
\hline \multicolumn{1}{|c|}{ Bacteria } & \multicolumn{1}{c|}{ Dye } & \multicolumn{1}{c|}{ Reference } \\
\hline Xenophilus azovorans & Carboxy Orange II & Blumel et al., (2002) \\
\hline Aeromonas hydrophilia & $\begin{array}{l}\text { Acid Orange-7, } \\
\text { Acid Red-106 }\end{array}$ & Chen et al., (2003) \\
\hline Escherichia coli & Reactive Red-21 & Chang et al., (2004) \\
\hline Kocuria rosea MTCC 1532 & Malachite Green & Parshetti et al., (2006) \\
\hline Pseudomonas desmolyticum & Direct Blue-6 & Kalme et al., (2007) \\
\hline Vibrio harveyi & Acid Black-210 & Ozdemir et al., (2008) \\
\hline Pseudomonas sp. SUK-1 & Reactive Red-22 & Kalyani et al., (2009) \\
\hline Klebsiella sp. & Orange 3R & Ponraj et al., (2011) \\
\hline Enterobacter sp. VP-64 & Crystal violet & Hemapriya and Vijayanand (2014) \\
\hline Escherichia coli AK-12 & Evan's blue & Aswinkumar et al., (2017) \\
\hline
\end{tabular}




\section{Treatment methods used in bioremediation} of the effluents

Treating the effluents from the waste water industries involved the three different methods namely physical, chemical and biological treatment methods. Sometimes, a combination of two methods is used for the treatment procedure

\section{Physio-chemical treatment methods}

Physical methods involved the usage of physical features such as coagulation (Sengil et al., 2009), sedimentation (Song et al., 2000), filtration (Tiglyene et al., 2008), flotation (Murugananthan et al., 2004), precipitation, adsorption (Physical, chemical and ionic) (Kabir and Ogbeide, 2009). Tannery waste are treated using a noval approach called as electrochemical oxidation process in which the effluent treated with two systems such as electrolytic and physicochemical systems (El-Sheikh et al., 2011).

A newer approach was initiated which includes nanoparticle adsorption and magnetic separation of $\mathrm{Cr}$ from the waste water. A research study carried out by Jing $e t$ al., 2005proved that the removal of chromium from tannery waste is possible by use of maghemite nanoparticles. When using maghemite as adsorbent, maximum adsorption of $\mathrm{Cr}$ was achieved at $\mathrm{pH} 2.5$. Using Hydrogen peroxide $\left(\mathrm{H}_{2} \mathrm{O}_{2}\right)$, hypochlorites of calcium and sodium aids in the recovery of chromium from the tannery effluents. Hydrogen peroxide showed a remarkable chromium recovery from the waste water. Nearly $98 \%$ of the chromium can be recovered and re-used. Due to these agents, the oxidation of chromium(III) to chromium(VI) can be reduced greatly and make a reduction in environmental pollution (Ali awan et al., 2003).

\section{Biological methods of effluent treatment}

Biological method of effluent treatment is an important as easy procedure where, the treatment process is carried out using biological substance such as microorganisms which widely included bacteria and fungi. It is considered to be the most advantageous process with less undesirable features when compared with the other techniques. Remediation process is carried out by microbes using two different mechanisms namely aerobic and anaerobic methods. Bioremediation is one of the famous methods for the treatment of tannery waste. It has been implemented successfully in many countries. Biological treatment methods are cost effective than physico - chemical methods. Numerous microorganisms possess the capability of breaking of these pollutants to obtain energy and nutrients for their growth (Metcalf and Eddy, 2003). Biological methods of textile effluent treatment are mediated by both bacterial consortium (Table 1) and pure cultures of bacterial isolates (gram positive and gram negative) (Table 2 and 3).

Most of the microorganisms are capable of reducing the hexavalent chromium $[\mathrm{Cr}(\mathrm{VI})]$ to trivalent chromium [Cr (III)]. So, Bioremediation plays an essential role in the removal of toxicity from $\mathrm{Cr}(\mathrm{VI})$. Certain MOs (Example: Pseudomonas sp) possess an enzyme called "chromium reduction" thus actively reduces $\mathrm{Cr}$ (VI) to $\mathrm{Cr}$ (III) (Arellano et al., 2004; Middleton et al., 2003). Sarker et al., (2013) revealed that certain microorganisms like bacteria, possess the ability of reducing $\mathrm{Cr}(\mathrm{VI})$ to $\mathrm{Cr}(\mathrm{III})$ either in the presence or absence of oxygen. Those organisms are referred as chromium reducing bacteria [CRB]. Anaerobic process employs anerobic bacteria which grows in the absence of oxygen that generally requires prolonged time for remediation process. This feature 
remains as a disadvantage of the anaerobic process. The treatment system also gives a bad odor during reaction time. On the other hand, aerobic treatment is carried out using aerobic bacteria which requires oxygen for their steady growth. This treatment process is considered to be an effective process when compared with anaerobic treatment.

Activated sludge treatment is highly used for bioremediation using biological method. But this method is been considered as one of the expensive process both operational and maintenance wise (Midha and Dey, 2008). In general, tannery and other industrial effluents are reported for its degradation and remediation using microorganism. Several organisms such as Bacillus sp., Pseudomonas sp., E. coli, Flavobacterium sp., are reported for its efficacy in degrading the complex metals and other xenobiotics present in the effluent.

In conclusion the bioremediation has become a topic of interest to researchers all over the world due to its ability in degrading the challenging complex molecules in lesser incubation time with low-cost substrate and cheaper maintenance features. Newer bioremediation procedures are been introduced day by day to increase the degradation efficacy of the microbes against heavy metals and other pollutants released from the industries. Compared with chemical and other physical remediation treatment, biological treatment process results in the complete removal of the pollutant which physical and chemical process fail or achieve by consuming expensive mechanical and other resources.

\section{References}

Ali awan, M., Baig, M., Iqbal, J., Aslam, M., Ijaz, N., 2003. Recovery of chromium (III) from tannery wastewater . J. Appl. Sci. Environ. Manag. Bioline Int. 7, 5-8.
Arellano, H., Alcalde, M., Ballesteros, A., 2004. Use and improvement of microbial redox enzyme for environmental purposes. Microb. Cell Fact.

Arora, S., H.S.Saini and K.Singh. (2007). Decolorization optimization of a monoazo disperse with Bacillus firmus. Identification of a degradation product. Color. Technol., 123: 184-190.

Aswin Kumar, S., N. Arunagirinathan, S. Vijayanand, J. Hemapriya and Indra, V. 2017. Bioremediation and Detoxification of a Textile Azo Dye-Evans Blue by Bacterial Strain AKIP2 Int.J.Curr.Microbiol.App.Sci. 6(5): 26872694.

Balasubramanian, S., Pugalenthi, V., 2000. A comparative study of the determination of sulphide in tannery waste water by ion selective electrode (ISE) and iodometry. Water Res 34, 4201-4206.

Blumel. S., H.J.Knackmuss and A.Stolz. (2002). Molecular cloning and characterization of the gene coding for the aerobic azoreductase from Xenophillus azovorans KF44F. Appl. Environ. Microbiol., 68:3948-3955.

Chaudhary, P., Chhokar, V., Kumar, A., Beniwal, V., 2017. Bioremediation of Tannery Wastewater, Advances in Environmental Biotechnology,. https://doi.org/10.1007/978-981-10-40412

Dave, S.R. and R.H.Dave. (2009). Isolation and characterization of Bacillus thuringiensis for Acid Red-119 dye decolorization. 100:249-253.

Deng, D., J.Guo, G.Zeng and G.Sun. (2008). Decolorization of anthraquinone, triphenylmethane and azo dyes by a new isolated Bacillus cereus strain DC11. Int. Biodetor. Biodegrad., 62:263-269.

El-Sheikh, M., Saleh, H., Flora, J., 2011. Biological tannery wastewater treatment using two stage UASB reactors. Desalination. 276, 253-259.

Farag, S., Zaki, S., 2010. Identification of bacterial strains from tannery effluent and reduction of hexavalent chromium. J Env. 
Biol. 31, 877-882.

Hasegawa, M., Barbosa, A., Takashima, K., 2011. Biotreatment of industrial tannery wastewater using Botryosphaeria rhodina. J Serb Chem Soc. 76, 1-8.

Hemapriya, J., Rajesh Kannan and S.Vijayanand. (2010). Bacterial decolorization of textile azo dye Direct Red-28 under aerobic conditions. J.Pure Appl.Microbiol., 4(1):309-314.

Hemapriya, J and S.Vijayanand. (2013). Bioremediation of Structurally different textile dyes by a novel bacterial consortium.

Int.J.Curr.Microbiol.Appl.Sci., 2(11):212226.

Hemapriya, J. and S.Vijayanand. (2014). EcoFriendly Bioremediation of a Triphenylmethane Dye by Textile Effluent Adapted Bacterial Strain VP-64. Int. J. Current Microbiol. Appl. Sci., 3(9): 983- 992.

Jing, H., Guohua, C., Irene, M., 2005. Removal and recovery of chromium(VI) from waste water by maghemite nanoparticles. Water Res. 39, 4528-4536.

Kabir, G., Ogbeide, S., 2009. Removal of chromate in trace concentration using ion exchange from tannery wastewater. Int $\mathbf{J}$ Env. Res 2.

Kalme, S.D., G.K.Parshetti, S.U.Jadhav and S.P.Govindwar. (2007). Biodegradation of Benzidine based dye Direct Blue- 6 by Pseudomonas desmolyticum NCIM 2112. Bioresour. Technol., 98:1405-1410.

Kalyani, D.C., A.A.Telke, R.S.Dhanve and J.P.Jadhav. (2009). Eco-friendly biodegradation and detoxification of Reactive Red-2 textile dye by newly isolated Pseudomonas sp. SUK1. J. Haz. Mat., 163:735-742.

Khehra, M.S., H.S.Saini, D.K.Sharma, B.S.Chadha and S.S.Chimni. (2005). Comparative studies on potential of consortium and constituent pure bacterial isolates to decolorize azo dyes. Water Res., 39:5135-5141.

Kim, D.J., H.Y.An, J.H.Yoon, Y.H.Park, F.Kawai and C.M.Jung. (2002).
Identification of Clostridium perfringens $\mathrm{AB}$ and $\mathrm{J}$ and its uptake of Bromophenol Blue. J. Microbiol. Biotechnol., 12:544552.

Mabrouk, M.E.M. and H.H.Yusef. (2008). Decolorization of Fast Red by Bacillus subtilis HM. J. Appl. Sci. Res., 4(3):262269.

Metcalf, Eddy, 2003. Wastewater Engineering.

Middleton, S., Latmani, R., Mackey, M., 2003. Cometabolism of $\mathrm{Cr}(\mathrm{VI})$ by Shewanella oneidensis MR-1 Produces CellAssociated Reduced Chromium and Inhibits Growth., Wiley Inter. Science.

Midha, V., Dey, A., 2008. Biological treatment of tannery wastewater for sludge removal. Int J Chem Sci 6, 472-486.

Mohan, V., Devi, K., 2015. Diversity status of beneficial microorganisms in heavy metal polluted tannery effluent treatment area in Dindugal, Tamil Nadu. J Acad Ind Res 4,

Murugananthan, M., Raju, G., Prabhakar, S., 2004. Separation of pollutants from tannery effluents by electro flotation. Sep Purif Technol 40, 69-75.

Moosvi, S., X.Kher and D.Madamwar. (2007). Isolation, characterization and decolorization of textile dyes by a mixed bacterial consortium JW-2. Dyes. Pigments., 74:723-729.

Ozdemir, G., B.Pazarbasi, A.Kocyigit, E.E.Omeroglu, I.Yasa and I.Karaboz. (2008). Decolorization of Acid Black-210 by Vibrio harveyi TEMS1, a newly isolated bioluminescent bacterium from Izmir Bay, Turkey. World J. Microbiol. Biotechnol., 24:1375-1381.

Panda, G., Sarkar, P., 2012. Bioremediation of chromium by novel strains Enterobacter aerogenes T2 and Acinetobacter sp. PD 12 S2. Env. Sci Pollut Res 19, 18091817.

Parshetti, G., S.Kalme, G.Saratale and S.Govindwar. (2006). Biodegradation of Malachite Green by Kocuria rosea MTCC 1532. Acta Chim. Slov., 53:492498.

Phugare, S.S., D.C.Kalyani, A.V.Patil and J.P.Jadhav. (2011). Textile dye 
degradation by bacterial consortium and subsequent toxicological analysis of dye and dye metabolites using cytotoxicity, genotoxocity and oxidative stress studies. J. Haz. Mat., 186(1):713-723.

Ponraj, M., K.Gokila and V.Zambare. (2011). Bacterial decolorization of textile dyeOrange 3R. Int. J. Adv. Biotechnol. Res., 2(1):168-177.

Samrithi, A., Usha, K., 2012. Isolation and characterization of chromium removing bacteria from tannery effluent disposal site. Int J Adv Biotechnol Res 3, 644652.

Sarker, B., Bristy Basak, M., Islam, S., 2013. Chromium effects of tannery waste water and appraisal of toxicity strength reduction and alternative treatment. Int. J. Agron. Agric. Res. 3, 23-35.

Sengil, I., Kulac, S., OzacarM, 2009. Treatment of tannery liming drum wastewater by electrocoagulation. J hazard mater 167 , 940-946.

Song, Z., Williams, C., Edyvean, R., 2000. Sedimentation of tannery wastewater. Water Res 34, 2171-2176.

Tiglyene, S., Jaouad, A., Mandi, L., 2008. Treatment of tannery wastewater by infiltration percolation: chromium removal and speciation in soil. Env. Technol 29, 613-624.

Saratale, R.G., G.D.Saratale, D.C.Kalyani, J.S.Chang and S.P.Govindwar. (2009).
Enhanced decolorization and biodegradation of textile azo dye Scarlet $\mathrm{R}$ by using developed microbial consortium-GR. Bioresour. Technol., 100: 2493-2500.

Shyamala, A., J.Hemapriya, Kayeen Vadakkan and S.Vijayanand. (2014). Bioremediation of Methyl Orange, a Synthetic azo dye by a Halotolerant Bacterial strain. Int. J. Current Research and Academic Review. 2(8):373- 381

Vijayanand, S. and J.Hemapriya. (2013). Bacterial bioremediation of textile azo dyes A Review. Ind. J. Appl. Res., 3(12): 480-482.

Vijayanand, S., Kayeen Vadakkan and Hemapriya, J. 2017. Ecofriendly Bioremediation of Acid Orange - An Electron Deficient Xenobiotic Chromogen by Haloalkaliphilic Bacterial Consortium TVU- AO 64. Int.J.Curr.Microbiol.App.Sci., 6(4): 956963.

Vijaykumar, M.H., P.A.Vaishampayan, Y.S.Shouche and T.B.Karegoudar. (2007). Decolorization of naphthalenecontaining sulfonated azo dyes by Kerstersia sp. strain VKY1. Enz. Microbial Technol., 40:204-211.

Walker, G.M. and L.R.Weatherley. (2000). Biodegradation and biosorption of acid anthraquinone dye. Environ. Pollut., 108:219-223.

\section{How to cite this article:}

Barathi, A., J. Hemapriya, Ramya Gunasekaran, Kayeen Vadakkan, A. Shyamala, Aswini Ravi and Vijayanand, S. 2020. Bioremediation of Textile and Tannery Effluents - An Overview. Int.J.Curr.Microbiol.App.Sci. 9(11): 3782-3790. doi: https://doi.org/10.20546/ijcmas.2020.911.454 